\title{
シンポジウムIクドア属寄生虫一日韓の管理体制と最近の話題
}

- Symposium 1 Myxozoan Genus Kudoa - Control on Fish Farm in Japan and Korea, and Recent Topics-

\section{都内の粘液胞子虫がかかわる有症事例と魚介類の感染実態 調査}

Association between Myxozoan Parasites and Fish-Borne Diseases in Tokyo, and a Survey of the Myxosporean Infections in Marine Fishes

鈴 木 淳

(東京都健康安全研究センター)

Jun SuZukI

(Tokyo Metropolitan Institute of Public Health, Hyakunin-cho, Shinjuku-ku, Tokyo 169-0073)

\section{1. はじめに}

粘液胞子虫は，古くから罹患魚の筋肉をジェリー状に 融解することにより食品価值の低下の原因となる寄生虫 として知られてきた1,2)。これまで粘液胞子虫は，ヒト への病原性はないと考えられてきたが, 主にヒラメの 筋肉に寄生するKudoa septempunctataが，下痢や嘔吐 の原因となることが明らかとなり，2011年6月に $K$. septempunctataが食中毒原因物質に指定された ${ }^{3)}$ 。その 後5年が経過し，全国で年平均 31 事例の食中毒が報告 ${ }^{4)}$ されているが，行政機関や大学等による実態調査や検査 法の確立, 養殖ヒラメの生産にかかわる研究機関による K. septempunctataのヒラメへの感染防止策，養殖現場 における出荷前検査の導入などにより, 国産養殖ヒラメ の契食による食中毒は大きく減少した。しかしながら， 韓国から輸入される養殖ヒラメを原因とした食中毒対策 や都内でも散発事例が報告 ${ }^{5,6)}$ されているヒラメ以外の 魚種に寄生する粘液胞子虫が原因と考えられる下痢症へ の原因究明については十分になされてはいない.

今回，粘液胞子虫が関与する下痢症対策の一助となる ことを目的に，近年の都内で発生した粘液胞子虫が原因 と考えられた下痢や嘔吐を伴う有症事例への対応ととも に, 下痢症の推定原因食品となる主な魚介類として, ヒ
ラメ，マグロおよびカンパチにおける粘液胞子虫の寄生 状況について紹介する.

\section{2. 東京都における粘液胞子虫の検査}

東京都では，ヒラメに限らず魚介類の生食後，短時間 で下痢や嘔吐を起こした事例について，食中毒起因菌や 腸管ウイルスの検査だけでなく, 寄生虫のついても食品 や粪便の検査を実施している。保健所等より依頼された 食品検体について，魚 1 尾の場合には 6 力所（左右の腹 側, 背側，尾側), 切り身などでは大きさにより数力所 から筋肉 $50 \mathrm{mg}$ を採取し, 遺伝子抽出キットにより抽出 したDNA 抽出物を遺伝子検査用の試料とした。また, 有症者の糞便検体では，厚生労働省の事務連絡にある検 査法 ${ }^{7)}$ にほぼ準じてDNAを抽出し試料とした。得られ たDNA 抽出試料について, Table 1 に示した多種のク ドア属粘液胞子虫の $18 \mathrm{~S}$ rDNAを検出可能なリアルタイ ム PCRによるスクリーニング検査を実施し，遺伝子の 増幅が認められた場合には，18S rDNAまたは28S rDNAを標的としたコンベンショナルPCRを行い, PCR 増幅産物のシークエンス解析を行った。 また，有 症苦情にかかわる魚介類や市場流通魚を対象とした検査 では，顕微鏡下でその胞子の形態を確認し，顕微鏡下で クドア属粘液胞子虫が認められた場合には, 魚肉 $1 \mathrm{~g}$ 当

Table 1. スクリーニング用リアルタイムPCRのプライマーおよびプローブ

\begin{tabular}{lllll}
\hline \multicolumn{2}{c}{ プライマー名 } & 塩基配列 $\left(5^{\prime} \rightarrow 3^{\prime}\right)$ & 配列位置 & $\begin{array}{l}\text { GenBank } \\
\text { 登録番号 }\end{array}$ \\
\hline KuRT-F & (forward) & TGGTGCATGGCCGTTCTTA & $1234-1252$ & AB6693042 \\
KuRT-R & (reverse) & CTCGCTCGTTACCGGAATAAA & $1275-1295$ & AB693042 \\
KuRT-R2* & (reverse) & TCGTTCGTTACCGGAATAAACCT & $1272-1294$ & AB693042 \\
KuRT-P & (probe) & FAM-TTGGTGGAGTGATCTGT-MGB & $1254-1270$ & AB693042 \\
\hline
\end{tabular}

*: Unicapsula seriolae 用のプライマー

函 169-0073 東京都新宿区百人町 3-24-1 
たりの胞子数を計数した ${ }^{8)}$.

\section{3. 近年の都内における発生状況}

2014 年および 2015 年の 2 年間に，粘液胞子虫による 食中毒疑いの有症事例は 32 事例で, そのうち 16 事例 $(50 \%)$ が 9 月および10月の検体であった(Table 2). 32 事例中 18 事例において, 粘液胞子虫の胞子または遺伝 子が食品または有症者の糞便から検出され，その種類は Fig. 1 に示したK. septempunctata, Kudoa hexapunctata, Kudoa iwatai, Unicapsula seriolaeの 4 種と種不明のクド ア属粘液胞子虫であった. K. septempunctataは，9月お よび10月を中心に 32 事例中 7 事例 $(23 \%)$ から検出され たが, 11 事例 (34\%)ではK. septempunctata 以外の粘液 胞子虫が検出された。その内訳は，11事例中 3 事例から

Table 2. 都内の粘液胞子虫が原因と考えられた有症事例 (2014年, 2015年)

\begin{tabular}{|c|c|c|c|}
\hline 発生月 & 事例数 & $\begin{array}{l}\text { 陽性 } \\
\text { 事例数 }\end{array}$ & $\begin{array}{c}\text { 検出された粘液胞子虫 } \\
\text { (陽性事例数) }\end{array}$ \\
\hline 1月 & 2 & 1 & Kudoa septempunctata (1) \\
\hline 2 月 & 3 & 1 & Unicapsula seriolae (1) \\
\hline 3月 & 3 & 1 & U. seriolae $(1)$ \\
\hline 4月 & 2 & 1 & U. seriolae $(1)$ \\
\hline 7月 & 3 & 2 & Kudoa hexapunctata (2) \\
\hline 8月 & 1 & 0 & - \\
\hline 9月 & 9 & 6 & $\begin{array}{l}\text { K. septempunctata }(3) \\
\text { Kudoa iwatai }(1) \\
\text { Kudoa } \text { sp. (1) } \\
\text { U. seriolae (1) }\end{array}$ \\
\hline 10月 & 7 & 5 & $\begin{array}{l}\text { K. hexapunctata }(1) \\
\text { K. septempunctata }(3) \\
\text { U. seriolae (1) }\end{array}$ \\
\hline \multirow[t]{2}{*}{12 月 } & 2 & 1 & U. seriolae $(1)$ \\
\hline & 32 & 18 & \\
\hline
\end{tabular}

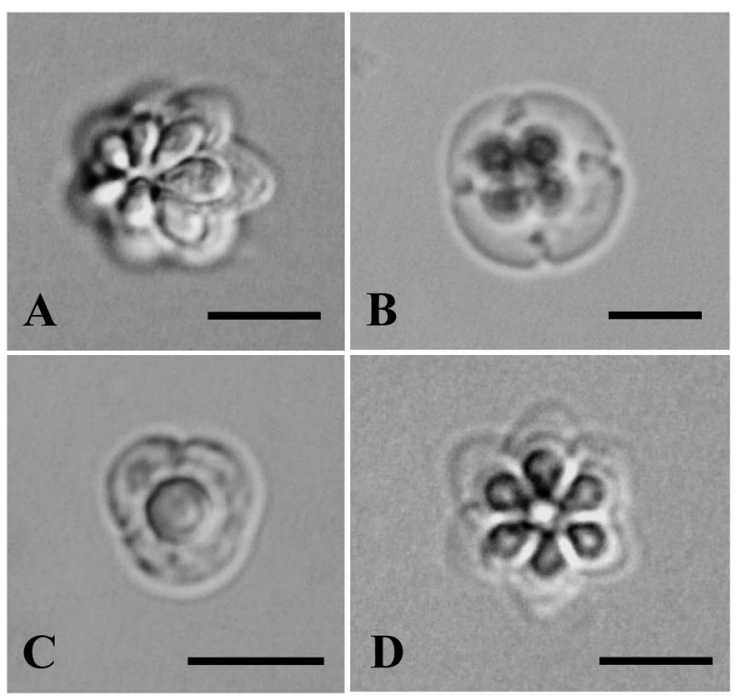

Fig. 1. 下痢症事例から検出された粘液胞子虫 A: Kudoa septempuctata, B: Kudoa iwatai, C: Unicapsula seriolae, D: Kudoa hexapunctata スケール: $5 \mu \mathrm{m}$
メジマグロ由来の K. hexapunctata, 6 事例からカンパチ 由来のU. seriolae, 1 事例からスズキ由来と考えられる K. iwatai, そして 1 事例から種不明のクドア属粘液胞子 虫の遺伝子が検出された。 3 事例中 2 事例が 7 月の検体 において検出されたK. hexapunctataは, 主に日本近海 のクロマグロの若魚であるメジマグロに高率に寄生し, 2014年に新種として報告されたクドア属粘液胞子虫で ある ${ }^{9)}$.これまでK. hexapunctataが残品のメジマグロ から検出された有症事例は 6 月および7月に多く, メジ マグロ $1 \mathrm{~g}$ 当たりの $K$. hexapunctata平均胞子数は $1.7 \times$ $10^{7}$ spores/gであった(Table 3). また，カンパチ由来の U. seriolaeによると考えられた有症事例は，2014年では 1事例であったが，2015年においては 5 事例に増加した。 5 月から 8 月の春から夏期における検体からU. seriolae は検出されなかったが, それ以外の時期の有症事例から は検出された(Table 2). 今後, カンパチに寄生する $U$. seriolaeが原因と疑われる食中毒様事例の増加が懸念さ れる。

その一方で, 34 事例中 14 事例では粘液胞子虫が検出 できなかったが，14事例中 11 事例においては，粘液胞 子虫の遺伝子検出が困難な糞便または食品の別ロット品 (参考品）の検査であった. これまでヒラメの K. septempunctataがかかわると考えられた有症事例において, 残品のヒラメからの陽性率が70\%であったのに対して, 参考品からの陽性率が $4.2 \%$ であった(Table 4). また,

Table 3. 都内有症事例におけるメジマグロ（残品）からの Kudoa hexapunctataの検出状況 (2009年〜2015年)

\begin{tabular}{|c|c|c|c|}
\hline \multirow[b]{2}{*}{ 発生月 } & \multirow[b]{2}{*}{ 推定原因食品 } & \multirow{2}{*}{$\begin{array}{c}\text { 顕微鏡検査 } \\
\text { 平均胞子数 } \\
\text { (spores/g) }\end{array}$} & \multirow{2}{*}{ 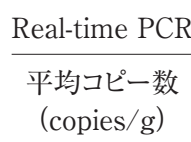 } \\
\hline & & & \\
\hline \multirow[t]{5}{*}{ 6月 } & メジマグロ & $8.1 \times 10^{6}$ & $5.6 \times 10^{9}$ \\
\hline & メジマグロ & $7.2 \times 10^{5}$ & $4.2 \times 10^{8}$ \\
\hline & メジマグロ & $9.4 \times 10^{6}$ & $5.2 \times 10^{9}$ \\
\hline & メジマグロ & $4.2 \times 10^{7}$ & $2.9 \times 10^{10}$ \\
\hline & メジマグロ & $4.5 \times 10^{6}$ & $4.7 \times 10^{9}$ \\
\hline \multirow[t]{3}{*}{ 7月 } & メジマグロ & $4.1 \times 10^{7}$ & $2.6 \times 10^{10}$ \\
\hline & メジマグロ & $7.4 \times 10^{6}$ & $4.5 \times 10^{9}$ \\
\hline & メジマグロ & $4.1 \times 10^{7}$ & $2.4 \times 10^{10}$ \\
\hline 8月 & メジマグロ & $9.8 \times 10^{6}$ & $5.3 \times 10^{9}$ \\
\hline 9月 & メジマグロ & $4.9 \times 10^{7}$ & $1.6 \times 10^{10}$ \\
\hline 10月 & メジマグロ & $1.0 \times 10^{6}$ & $6.4 \times 10^{8}$ \\
\hline \multirow[t]{2}{*}{12 月 } & メジマグロ & $2.0 \times 10^{6}$ & $1.5 \times 10^{9}$ \\
\hline & メジマグロ & $2.6 \times 10^{6}$ & $1.9 \times 10^{9}$ \\
\hline \multicolumn{2}{|c|}{ 平均值 } & $1.7 \times 10^{7}$ & $9.6 \times 10^{9}$ \\
\hline
\end{tabular}

Table 4. 有症事例のヒラメからのKudoa septempunctataの 検出状況（2009年～2015年)

\begin{tabular}{lccc}
\hline \multicolumn{1}{c}{ 検体の種類 } & 検体数 & 陽性数 & 陽性率 $(\%)$ \\
\hline 残品 & 20 & 14 & 70.0 \\
$\begin{array}{l}\text { 検食を含む) } \\
\text { 参考品 }\end{array}$ & 24 & 1 & 4.2 \\
\hline
\end{tabular}


有症者の瀵便検查では，喫食日から5 日以上経過した検 体から K. septempunctataの遺伝子を検出できなかった. さらに, 糞便からのK. hexapunctataおよびU. seriolae の検出状況も同様であったことや，下痢などの症状が一 過性であることから，少なくともこれらの粘液胞子虫は ヒトの腸管で定着や増殖はしないものと考えられる。し たがって, 粘液胞子虫がかかわる有症事例においては, 食品残品の検査と霬便検査では喫食から 4 日以内の採便 が重要であるといえる.

\section{4. 都内の食中毒事例}

食中毒とされた都内の事例として，2015年10月に， 寿司店でヒラメを喫食した 5 名中 2 名が下痢，嘔吐を起 こした事例では，有症者 2 名の糞便検体から K. septempunctataの遺伝子が検出された. 参考品のヒラメから $7.0 \times 10^{6} \mathrm{spores} / \mathrm{g}$ の K. septempunctataの胞子が検出さ れ, 当センターで検查した参考品から初めて K. septempunctataが検出された事例となった。聞き取り調查によ り，本事例は国内産の養殖ヒラメとして提供されていた が，実際には韓国産の養殖ヒラメが用いられていたこと が判明している. 国産養殖ヒラメより輸入養殖ヒラメの ほうが安価であることから，今後も同様の食中毒が起こ ることが危惧される。

カンパチの契食にかかわる有症事例として，2015年 4 月に，都内ホテルのビュッフェでカンパチの寿司を契食 した 13 名中 7 名が下痢と嘔吐を起こした事例，そして 2015 年 12 月には, ホテルのコース料理で提供されたカ ンパチを喫食した同一グループ 60 名中 10 名で下痢と嘔 吐を起こした事例が発生した，原因食品と推定されたカ ンパチ（検食）を検查した結果，2事例ともに検食であ るカンパチから U. seriolaeの胞子が確認され，U. seriolae $18 \mathrm{~S} \mathrm{rDNA}$ が $1 \times 10^{8} \mathrm{copies} / \mathrm{g}$ 以上検出された。 今 後, ヒラメの場合と同様に, ビュッフェや宴会等では, カンパチに寄生するU. seriolaeによる集団食中毒様事 例が起こる可能性が示唆された。

\section{5. 魚介類の粘液胞子虫の寄生状況}

市場流通魚介類における粘液胞子虫の寄生調查につい ては, 有症事例の多い魚種を対象に, 2012年に養殖七 ラメ 40 検体， 2011 年から 2013 年の 3 年間にメジマグロ 104 検体，2013年抢よび2014年の 2 年間にカンパチ 190 検体の検査を実施した。

養殖ヒラメを対象としたK. septempunctataの寄生調 查では陽性検体は認められなかったが，国産養殖ヒラメ 5 検体から四つの極囊を有するクドア属粘液胞子虫が検 出された，検出されたクドアは，既報10)の形態抒よび 18S rDNA の塩基配列から Kudoa lateolabracis と同定さ れた(Table 5)。.K. lateolabracisは, Kudoa thyrsites と 同様に魚のジェリーミートの原因となるクドア属粘液胞 子虫であるが，これまで都内に扔いて有症事例はない．
Table 5. 市場流通の養殖ヒラメにおける粘液胞子虫の寄生 調査（2012年）

\begin{tabular}{ccccc}
\hline $\begin{array}{c}\text { 検查 } \\
\text { 実施月 }\end{array}$ & 産地 & 検体数 & 陽性数 & $\begin{array}{c}\text { 検出された粘液 } \\
\text { 胞子虫 }\end{array}$ \\
\hline 7 月 & 千葉県 & 4 & 1 & Kudoa lateolabracis \\
& 韓国 & 4 & 0 & - \\
8 月 & 大分県 & 4 & 0 & - \\
& 韓国 & 4 & 0 & - \\
9 月 & 愛媛県 & 4 & 2 & K. lateolabracis \\
& 大分県 & 4 & 0 & - \\
& 韓国 & 8 & 0 & - \\
10 月 & 千葉県 & 4 & 2 & K. lateolabracis \\
& 韓国 & 4 & 0 & - \\
\hline 合計 & & 40 & 5 & \\
\hline
\end{tabular}

Table 6. メジマグロにおけるKudoa hexapunctataの検出状 況 (2011年〜2013年)

\begin{tabular}{crccc}
\hline $\begin{array}{c}\text { 検査 } \\
\text { 実施月 }\end{array}$ & 検体数 & $\begin{array}{c}\text { 陽性数 } \\
(\%)\end{array}$ & $\begin{array}{c}10^{9} \mathrm{copies} / \mathrm{g} \\
\text { 以上の陽性数(\%) }\end{array}$ & $\begin{array}{c}\text { 平均コピー数 } \\
\text { (copies } / \mathrm{g})\end{array}$ \\
\hline 1 月 & 7 & $3(42.9)$ & $1(14.3)$ & $6.9 \times 10^{8}$ \\
2 月 & 6 & $4(66.7)$ & $2(33.3)$ & $3.7 \times 10^{9}$ \\
4 月 & 3 & $2(66.7)$ & $1(33.3)$ & $8.5 \times 10^{8}$ \\
5 月 & 6 & $6(100)$ & $4(66.7)$ & $3.5 \times 10^{9}$ \\
6 月 & 13 & $11(84.6)$ & $8(61.5)$ & $2.5 \times 10^{9}$ \\
7 月 & 12 & $11(91.7)$ & $8(66.7)$ & $5.2 \times 10^{9}$ \\
8 月 & 12 & $8(66.7)$ & $5(41.7)$ & $1.9 \times 10^{9}$ \\
9 月 & 5 & $4(80.0)$ & $1(20.0)$ & $2.7 \times 10^{9}$ \\
10 月 & 7 & $4(57.1)$ & $2(28.6)$ & $1.3 \times 10^{9}$ \\
$11 月$ & 15 & $6(40.0)$ & $2(13.3)$ & $4.4 \times 10^{8}$ \\
12 月 & 18 & $8(44.4)$ & $3(16.6)$ & $1.1 \times 10^{9}$ \\
\hline 計 & 104 & $67(64.4)$ & $37(35.6)$ & $2.1 \times 10^{9}$ \\
\hline
\end{tabular}

メジマグロに扔けるクドア属粘液胞子虫の寄生調査で は, 67 検体(64.4\%)から K. hexapunctataが検出され, その $18 \mathrm{~S}$ rDNAの平均コピー数は $2.1 \times 10^{9} \mathrm{copies} / \mathrm{g}$ で あった(Table 6)。また，1尾当たり6力所を検査し，い ずれの部位からも検出された 58 検体では，魚の筋肉部 位に打けるK. hexapunctataの寄生分布に差が認められ なかった。その一方，メジマグロの重量が $8 \mathrm{~kg}$ を超え た9検体に打いては，部位により寄生にばらつきが認め られた。ささら，5月から 7 月に流通する $5 \mathrm{~kg}$ 以下のメ ジマグロにおいて，K. hexapunctataの陽性率, 寄生量 がともに高く，有症事例の発生時期と一致していた。 ま た，これまでの調査結果からメジマグロの成魚であるク ロマグロに打けるK. hexapunctataの寄生率は約 10\%で, $18 \mathrm{~S} r \mathrm{DNA}$ の平均コピー数もメジマグロの1/20であった ことから，マグロの成長とともにK. hexapunctataが消失 することが推察された ${ }^{11)}$ 。また，都内においてクロマ グロ（成魚）の喫食を原因とする有症事例は発生してい ない.

カンパチにおける寄生調查では, 190 検体中 11 検体 $(5.7 \%)$ から U. seriolaeが検出され，そのうち，3検体で は U. seriolae $18 \mathrm{~S} \mathrm{rDNA} か ゙ 1 \times 10^{8} \mathrm{copies} / \mathrm{g}$ 以上検出さ れた(Fig. 2)。また，U. seriolaeが検出された11検体中 


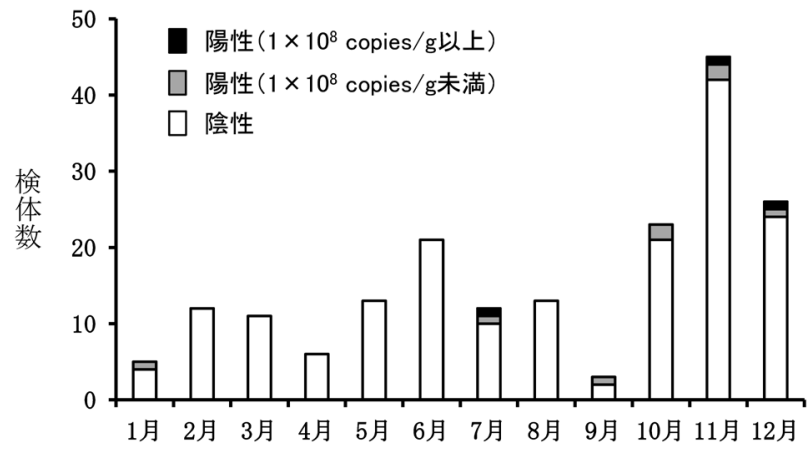

Fig. 2. 月別の市場流通カンパチにおけるUnicapsula seriolaeの検出状況（2013年, 2014年）

Table 7. イムノクロマト法によるKudoa septempunctata検出 キットの特異性

\begin{tabular}{lll}
\hline 粘液胞子虫 & 魚種 & 結果 \\
\hline Kudoa septempunctata & ヒラメ & $(+)$ \\
K. thyrsites & & $(-)$ \\
K. lateolabracis & & $(-)$ \\
K. ogawai & & $(-)$ \\
\hline K. hexapunctata & クロマグロ & $(+)$ \\
K. neothunni & キハダマグロ & $(+)$ \\
\hline Unicapsula seriolae & カンパチ & $(-)$ \\
\hline
\end{tabular}

8 検体が，9月から 12 月および1月に流通したカンパチ で，9から 12 月の有症事例の発生と市場流通のカンパチ からの検出状況との一致が認められたが，有症事例数が 少ないことから，今後の発生動向を注視する必要があ る.

\section{6. イムノクロマト法の特異性}

2016年 4 月にK. septempunctataの検査法が改正され, スクリーニング検查法として新たにイムノクロマト法が 追加された ${ }^{8)}$. 現在，市販されているキットは，K. septempunctata検出キット (ARK Checker IC Kudoa septempunctata $\mathrm{M}$ ，アークリソース）のみで，本キットを 用いて，これまでにヒラメの筋肉から検出された $K$. septempunctata, K. lateolabracis, Kudoa thyrsites, Kudoa ogawai, メジマグロやキハダマグロの筋肉から検出 されたK. hexapunctata, Kudoa neothunni, そしてカン パチの U. seriolae との交差反応性を確認したところ, ク ロマグロやキハダマグロに寄生するK. hexapunctata 掠 よびKudoa neothunniが陽性となった(Table 7)。K. septempunctata 検出用のイムノクロマトキットをヒラメ 以外の魚介類で使用するケースは考えにくいが，陽性で あった場合には胞子の形態を確認する必要性がある。

\section{7. 今後の課題}

現在，クドア属だけでも 100 種近い種類が報告 ${ }^{12)} さ$ れているが，その生活環，感染経路などが解明されてい るのはごく一部で, K. septempunctataの生活環も完全
に解明されていない. K. septempunctataについては, Caco-2細胞に対する細胞毒性や乳のみマウスにより実 験的に下痢原性が確認され ${ }^{13,14)}$ ，食中毒起因物質に指 定されたことにより, 食中毒の発生状況を把握すること が可能となっている，その一方で，メジマグロやカンパ チ等の生食により，一過性の下㾥や嘔吐等を呈する有症 事例が都内だけでなく全国的にも散見されている ${ }^{4,5,15)}$ が, 学会等で報告されなければ, その発生状況の把握が 困難である．現在，メジマグロに寄生するK. hexapunctataについては, Caco-2細胞に対する細胞毒性やマウス による下痢原性が確認されたが，K. sepetmpunctataの 10 倍量の胞子数が必要であることがわかってきた ${ }^{10)}$. 今後，さらなる事例の蓄積を全国的に行う必要性と毒性 試験等の科学的根拠に基づき, K. septempunctata以外 の粘液胞子虫によると考えられる健康被害を未然に防止 する対策が求められる.

\section{謝辞}

本研究において, クドアの分類に関するご指導, ご助 言をいただきました東京大学大学院農学生命科学研究科 の横山 博博士に深謝いたします.

\section{文献}

1) Gilchrist, J, D. F.: A protozoal parasite (Chloromyxum thyrsites sp. n.) of the cape sea-fish, the "snoek" (Thyrsites atun, Euphr.). Trans. R. Soc. S. Afr., 11, 263-273 (1923).

2) Kudo, G., Barnett, H. J. and Nelson, R. W.: Factors affecting cooked texture quality of Pacific whiting, Merluccius productus, fillets with particular emphasis on the effect of infection by the myxosporeans Kudoa paniformis and K. thyrsites, Fish. Bull., 85, 745-755 (1987).

3）厚生労働省医薬食品局食品安全部長：生食用生鮮食品に よる病因物質不明有症事例への対応について，平成 23 年6月 17 日，食安発 0617 第3号 (2011).

4）杉山 広：食中毒としての食品媒介寄生虫症：現状と検 査の課題. 日食微誌, 33, 134-137 (2016).

5）鈴木 淳, 村田理恵, 新開敬行, 貞升健志：都内で発生 したクドアによる食中毒事例. Clin. Parasitol., 26, 104106 (2015).

6）鈴木 淳, 日向綾子, 村田理恵, 新開敬行, 貞升健志： 都内における粘液胞子虫が原因と推定された下㾥症事 例. Clin. Parasitol., 27, 54-56 (2016).

7）厚生労働省医薬食品局食品安全部監視安全課：食中毒患 者便からの Kudoa septempunctata 遺伝子検出法（参考） について，平成 26 年 5 月 26 日，事務連絡 (2014).

8）厚生労働省医薬食品局食品安全部監視安全課長：Kudoa septempunctataの検査法について。平成 28 年 4 月 27 日, 生食監発0427第3号 (2016).

9) Yokoyama, H., Suzuki, J. and Shirakashi, S.: Kudoa hexapunctata n. sp. (Myxozoa: Multivalvulida) from the somatic muscle of Pacific bluefin tuna Thunnus orientalis and re-description of $K$. neothunni in yellowfin tuna T. albacares. Parasitol. Inter., 63, 571-579 (2014). 
10) Yokoyama, H., Whipps, C. M., Kent, M. L., Mizuno, K. and Kawakami, H.: Kudoa thyrsites from Japanese flounder and Kudoa lateolabracis n. sp. from Chinese sea bass: causative myxozoans of post-mortem myoliquefaction. Fish Pathology, 39, 79-85 (2004).

11) Suzuki, J., Murata, R., Yokoyama, H., Sadamasu, K. and Kai, A.: Detection rate of diarrhoea-causing Kudoa hexapunctata in Pacific bluefintuna Thunnus orientalis from Japanese waters. Int. J. Food Microbiol, 194, 1-6 (2015).

12) Eiras, J. C., Saraiva, A. and Cruz, C.: Synopsis of the species of Kudoa Meglitsch, 1947 (Myxozoa: Myxosporea: Multivalvulida): Syst. Parasitol., 87, 153-180 (2014).
13) Kawai, T., Sekizuka, T., Yahata, Y., Kuroda, M., Kumeda, Y., Iijima, Y., Kamata, Y., Sugita-Konishi, Y. and Ohnishi, T.: Identification of Kudoa septempunctata as the causative agent of novel food poisoning outbreaks in Japan by consumption of Paralichthys olivaceus in raw fish. Clin. Infect. Dis., 54, 1046-1052 (2012).

14) Ohnishi, T., Kikuchi, Y., Furusawa, H., Kamata, Y. and Sugita-Konishi, Y.: Kudoa septempunctata invasion increases the permeability of human intestinal epithelial monolayer. Foodborne Pathog. Dis., 10, 137-142 (2013).

15）大西貴弘, 都丸亜希子, 吉成知也, 鎌田洋一, 小西良 子：生鮮魚介類の生食に関連した有症苦情事例残品に含 まれる粘液胞子虫の検出. 日食微誌, 33, 150-154 (2016). 